\title{
Technology of receiving fresh water from forcedly saturated air through the use of solar energy
}

\author{
Victor Mironov ${ }^{1}$, Yuriy Ivanyushin ${ }^{1, *}$, Evgeniy Zhernakov $^{1}$, Dmitriy Mironov $^{2}$, Oleg \\ Stepanov $^{1}$, Olga Sidorenko ${ }^{1}$ \\ ${ }^{1}$ Industrial University of Lunacharskogo str., 2, 625001, Tyumen, Russia \\ ${ }^{2}$ LLC “ELECTRORAM", Production Department, Przewalskogo str., 33/1, ap.79, 652023, Moscow, \\ Russia
}

\begin{abstract}
At present, as a result of climate change and man-caused impact on the environment, fresh drinking quality water deficit is observed in many regions of the world. The sufficiency of fresh water provides high quality of living, the stabilization of the internal and foreign political situation, especially in developing countries. A lot of fresh drinking quality water production technologies are known today. Most of them consume a significant amount of energy and pose a considerable danger to the environment. As a source of energy, as a rule, hydrocarbon raw material is used, which is an exhaustible resource. The authors developed a technology for obtaining fresh water of drinking quality from atmospheric air using the solar energy. The article provides a substantiation of the way of fresh water production from air and also describes the energy balance in its implementation.
\end{abstract}

\section{Introduction}

Out of the total volume of water resources on our planet, only 2.5-3.0 percents refer to sources of fresh water, while only a small part of them are available for use and not all of them are of drinking quality. The problem of providing mankind with fresh water of drinking quality has recently become quite acute. Prerequisites for its occurrence are several factors, including: the growth of the world's population, the uneven distribution of water resources on the planet, climatic changes, etc. [1].

Today, there are many technical solutions designed to solve this problem. Various methods of desalination of sea water are known, which are widely used in the world, including distillation and reverse osmosis technologies [2, 3]. Reverse osmosis has a significant drawback associated with the need to periodically replace the consumable material - reverse osmosis membranes. Distillation technology requires significant energy consumption, usually obtained by burning hydrocarbon raw material, which is a nonrenewable $[4,5]$. Most of the technologies used today in the world for desalination of sea water are designed for high productivity of fresh water, more than $20 \mathrm{~m}^{3}$ per hour.

\footnotetext{
* Corresponding author: ivanyushin_yuriy@mail.ru
} 
However, in many cases there is a need of desalination plants of small (up to 200 liter per hour) and medium (under $20 \mathrm{~m}^{3}$ per hour) capacity [6].

Small and medium-capacity technologies of seawater desalination include condensation process for producing fresh water from atmospheric sea air, devoid of the above disadvantages [7]. The physical and chemical characteristics of such condensate are very high. The final product contains less amount of toxic metals, practically doesn't have bacteriological contamination, and is characterized by a low content of deuterium, which negatively affects human life activity [8]. However, the performance of existing condensation technologies for fresh water with natural condensation is very low. In case of implementing forced condensation, additional energy costs arise.

The article considers the technology of obtaining fresh water from atmospheric air by condensation using renewable, ecologically clean solar energy.

\section{Technology description}

Modular units are proposed for condensate production (figure 1). The operating principle of modular plants is based on the forced saturation of atmospheric air with moisture due to the heating and evaporation of sea water by the sun, followed by the release of moisture in a cold condenser located underneath sea level [9].

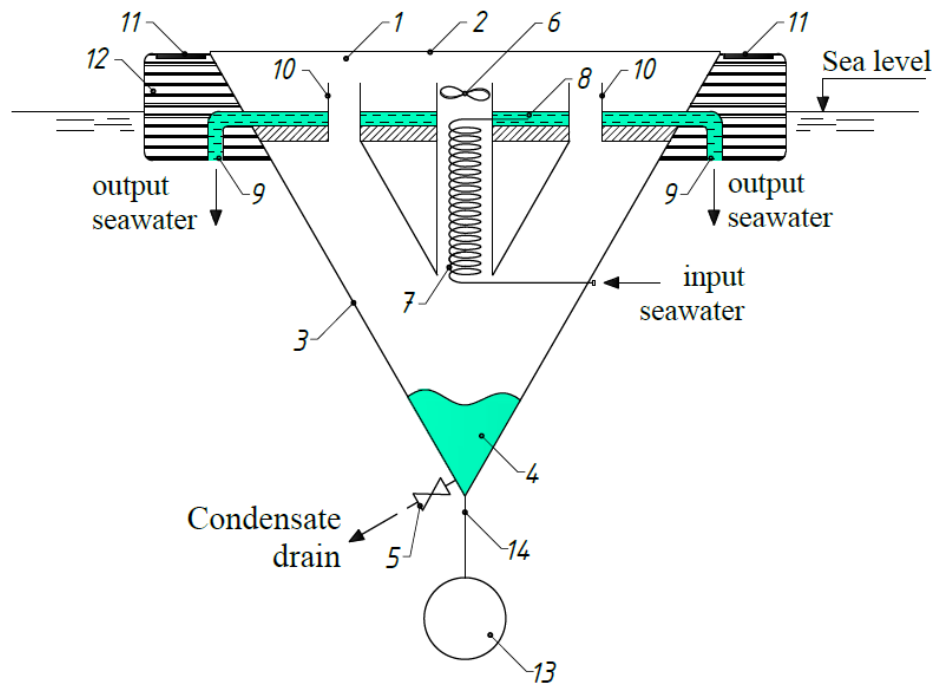

Fig. 1. Schematic diagram of the module, where: 1 - thermally insulated tank for heating and evaporation of sea water; 2 - a light-permeable surface for collecting the radiant energy of the sun; 3 moisture condenser located below sea level; 4 - pure fresh water; 5 - fresh water pipe; 6 - solar energy driven fan for circulating water vapor saturated air; 7 - heat exchanger for heating and supplying sea water to the evaporation vessel; 8 - a layer of heated sea water; 9 - openings to circulate sea water to prevent scaling; 10 - nozzles for passing dry cold air; 11 - solar photovoltaic cells; 12 - float ensuring positive buoyancy of the module; 13 - balance weight, providing a buoyancy and stability of the plant; 14 - cable rope for securing the balance weight.

A modular plant for obtaining fresh water from the air by condensation of moisture operates in a closed thermodynamic air cycle, which eliminates air purification from different kinds of impurities and simplifies the unit. During the unit operation heat recovery is used. Heat is released on the heat exchanger (7) when moisture condenses from the air. The heat exchanger (7) is a device for heating and supplying seawater to a thermally insulated tank (1) due to the difference in densities of cold and heated seawater. 


\section{Thermal balance modules}

Let's consider the process of obtaining fresh water (condensate) from the air, using the technology described above. In general, without taking into account the thermal losses of modular plants the energy balance has the following form:

$$
E_{s}=Q_{\text {air }}+Q_{\text {water }}+Q_{\text {evo }} \text {, }
$$

where $E_{s}$ is supplied solar energy, J/sec; $Q_{\text {air }}$ - the heat input for incoming dry air heating, $\mathrm{J} / \mathrm{sec} ; Q_{\text {evo }}$ - absorbed heat during the evaporation of sea water inside the floating buoy tank (1), J/sec; $Q_{\text {water }}$ - the heat input for seawater heating without the use of condensation heat recovery, $\mathrm{J} / \mathrm{sec}$.

The supplied solar energy can be determined from equation:

$$
E_{s}=N \cdot S \text {, }
$$

where $N$ is the solar radiation power, $\mathrm{W} / \mathrm{m}^{2} ; S$ is the insolation area, $\mathrm{m}^{2}$.

In the process of insolation, the temperature potential of the air increases inside the vessel of the plant (1) with transferring the amount of heat $Q_{\text {air }}$ :

$$
Q_{\text {air }}=c_{\text {air }} \cdot M_{w a} \cdot\left(T_{2}-T_{1}\right) \text {, }
$$

where $T_{1}$ is the temperature of the cooled air incoming to the tank (1), equal to the temperature of the surrounding sea water, $\mathrm{K} ; c_{\text {air }}$ - average specific heat of air, $\mathrm{J} / \mathrm{kg} \cdot \mathrm{K}$, in the range of operating temperatures; $M_{w a}$ - mass flow rate of incoming air, $\mathrm{kg} / \mathrm{sec} ; T_{2}$ is the temperature inside the heat insulated tank (1) in floating buoy, $\mathrm{K}$.

Wet air is considered as a mixture of individual components: dry air and moisture vapor. In this case, the density of moist air can be determined from the partial pressures according to the known expression [10]:

$$
\rho_{w a}=\frac{\varphi \cdot p_{1} \cdot \mu_{w a t e r}+\left(p_{a t m}-\varphi \cdot p_{1}\right) \cdot \mu_{\text {air }}}{R_{0} \cdot T_{1}}
$$

where $\varphi$ is the relative humidity of air in the buoy tank; $\mu_{\text {water }}-$ molar mass of moisture vapor (water), $\mathrm{kg} / \mathrm{mole} ; \mu_{\text {air }}$ - molar mass of air, $\mathrm{kg} / \mathrm{mole} ; R_{0}$ is the universal gas constant, $\mathrm{J} /($ mole $\cdot \mathrm{K}) ; p_{1}-$ is the partial pressure of saturated vapor, determined from the dependence [11]:

$$
p_{1}=\left(1.0016+\frac{3.15 \cdot p_{a t m}}{10^{8}}-\frac{7.4}{p_{a t m}}\right) \cdot 611.2 \cdot e^{\frac{17.62 \cdot T_{2}^{C}}{243.12+T_{2}^{C}}}
$$

where $\mathrm{T}_{2}{ }^{\mathrm{C}}$ is the temperature in the buoy tank in degrees Celsius, ${ }^{\circ} \mathrm{C}$.

Calculation by formulas (4) and (5) showed that in a given range of temperature changes the density of the air-vapor mixture at atmospheric pressure varies insignificantly, therefore, the mass flow of air dried in the condenser and saturated with moisture in the buoy tank (1) during its circulation in closed thermodynamic cycle can be considered identical.

Heat absorbed during evaporation of moisture from the water surface in the buoy tank $Q_{\text {evo }}, \mathrm{J} / \mathrm{sec}$ :

$$
Q_{\text {evo }}=c_{\text {evo }} \cdot M_{i},
$$

where $c_{\text {evo }}$ is the specific heat of evaporation, Joules $/ \mathrm{kg} ; M_{i}-$ mass flow of evaporating water, $\mathrm{kg} / \mathrm{sec}$. 
The amount of heat released during the condensation of moisture in the heat exchanger (7) of the floating buoy:

$$
Q_{\text {con }}=c_{\text {hex }} \cdot M_{k},
$$

where $c_{\text {hex }}$ is the specific heat of condensation Joules $/ \mathrm{kg} ; M_{k}$ is the mass flow rate of the condensate on the surface of the heat exchanger (7) $\mathrm{kg} / \mathrm{sec}$.

The remaining heat of condensation that is not used in the thermodynamic cycle is lost to the environment when moisture is deposited in the condenser (3). This heat of condensation is determined by the formula:

$$
Q_{\text {con }}^{k}=c_{h e x} \cdot M_{k}^{k}
$$

where $M_{k}{ }^{k}$ is the mass flow rate of the condensate in the condenser (3), $\mathrm{kg} / \mathrm{sec} ; \mathrm{Q}_{\mathrm{k}}{ }^{\text {con }}$ is the heat of condensation released into the environment, $\mathrm{J} / \mathrm{sec}$.

The sum of the mass flows $M_{k}^{k}$ and $M_{k}$ is equal to the mass flow of the evaporating water $M_{i}$ under the condition that the heat exchange surface of the condenser (3) is sufficient to ensure complete condensation of moisture.

The equation of the heat balance of the closed air cycle with the recuperation of the heat of condensation for the supply and heating of seawater can be presented separately for the floating buoy tank (1) of the unit and the heat exchanger (7) (fig.1) The separate heat balance is composed on the condition that the heat $E_{P}$, obtained upon insolation of the buoy tank (1), is used only for evaporation of sea water in the tank and heating of the incoming dried air.

The heating of the seawater incoming into the buoy tank is carried out by recuperating the condensation heat $Q_{c o n}$ released during the precipitation of moisture on the heat exchanger (7) and also by cooling the moisture-containing air when it moves into the condenser (3). In this case, the heat balance equations have the form:

- for the buoy tank (1):

$$
E_{s}=Q_{\text {air }}+Q_{\text {evo }} \text {; }
$$

- for heating of incoming seawater in the heat exchanger (7):

$$
c_{\text {air }} \cdot M_{w a} \cdot\left(T_{2}-T_{1}\right)+Q_{c o n}=Q_{\text {water }}^{r} .
$$

The energy spent for heating the seawater supplied to the vessel (1), taking into account the heat recovery in the heat exchanger (7), $Q_{\text {water }}, \mathrm{J} / \mathrm{sec}$ :

$$
Q^{r}{ }_{\text {water }}=c_{\text {water }} \cdot M \cdot\left(T_{2}-T_{1}\right),
$$

where $c_{\text {water }}$ is the heat capacity of incoming sea water, $\mathrm{J} /(\mathrm{kg} \cdot \mathrm{K}) ; M$ is the mass flow rate of seawater entering the tank (1) due to the difference in the densities of hot and cold water, $\mathrm{kg} / \mathrm{sec}$.

It should be noted that the mass flow of heated water $M$, and the mass flow of water $M_{i}$, evaporated from the surface of the buoy, are not equal to each other. Their difference, $\Delta M=M-M_{i}$, is a value constantly circulating in volume (1) of buoy. The water flow corresponding to $\Delta M$ is intended for the constant renewal of seawater in the vessel (1) of the buoy, since during the operation of the unit the total salt content increases with the evaporation of seawater. To avoid this, a regular washing of the vessel (1) with heated seawater with a low salt concentration is necessary.

The amount of moisture carried by air in a closed thermodynamic cycle, per unit of time, should be less than the evaporation intensity of heated water from its surface inside the tank (1), fig.1. The analysis of the many empirical formulas [12-15] to determine the intensity of water evaporation $\left(\mathrm{kg} / \mathrm{m}^{2} \cdot \mathrm{sec}\right)$ with its free surface depending on the 
temperature and air flow rate showed that in a given range of changes of temperature and air flow velocity in the tank (1) of the plant, the rate of evaporation is much greater than the possibility of moving the moisture mass flow of steam-air mixtures, determined from the energy balance taking into account the maximum power of insolation of one kilowatt per unit of surface evaporation.

\section{Results}

Using the presented dependences of the thermal energy balance in modular units and known data on the maximum moisture content of atmospheric air at different temperatures, graphical dependencies were derivated and plotted (Figures 2-5). These are graphs for determining the mass flow rate of condensed water in modular plants and the required insolation power, depending on the temperature of the heated steam-air mixture, at fixed values of the volumetric flow rates of the circulating vapor-air mixture and ambient temperatures. All of the above parameters are given per unit area of insolation. It should be noted that the insolation power cannot exceed one kilowatt $/ \mathrm{m}^{2}$. The upper temperature limit $T_{1}$ inside the heat-insulated capacity of the floating buoy was assumed to be $70^{\circ} \mathrm{C}$. At higher temperatures the formation of scale and deposition of hardness salts in the tank of the buoy occurs. And it negatively affects the operation of the unit. The amount of scale formed at a water temperature of about $80^{\circ} \mathrm{C}$ is seven times exceeds the amount of scale at a heating temperature of up to $60^{\circ} \mathrm{C}$. The operating mode of the modular plant at temperatures above $70^{\circ} \mathrm{C}$ is inadmissible.

Curve analysis (Fig. 2-5) indicated that with the increase in fan performance in a given temperature range $T_{2}$ from $45^{\circ} \mathrm{C}$ to $70^{\circ} \mathrm{C}$, the performance of modular units for fresh water increases, but also the necessity in insolation power is also rising, while it is limited to one $\mathrm{KW} / \mathrm{m}^{2}$. With the increase in the temperature of the surrounding seawater, the productivity of modular fresh water plants also increases with all other conditions being equal.

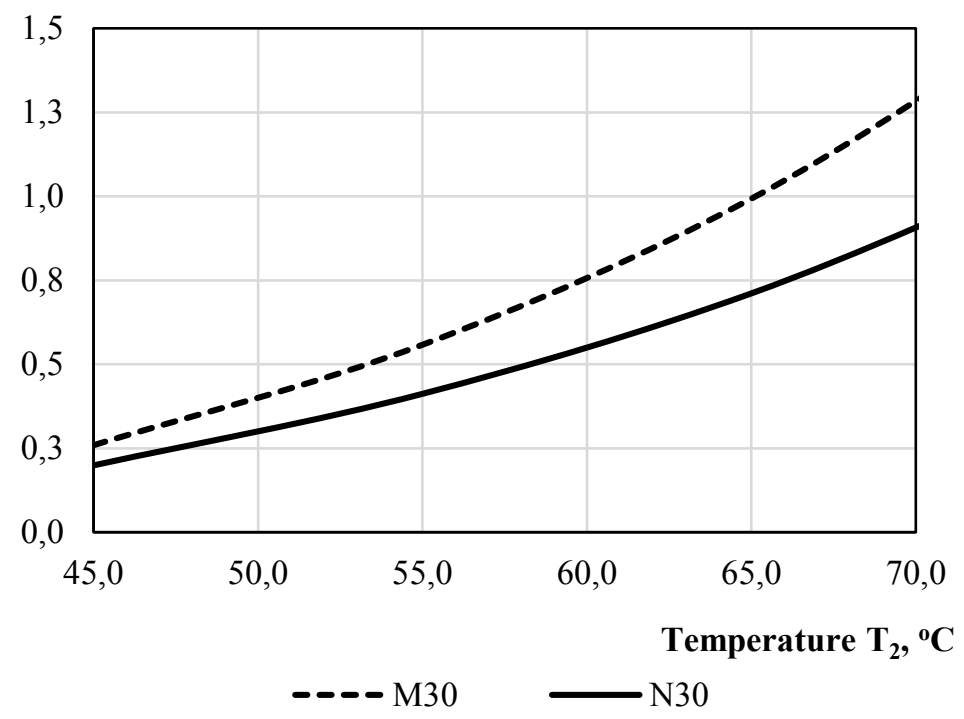

Fig. 2. Condensate mass flow rate (curve - M30, kg/hour) and power of required insolation (curve $\left.\mathrm{N} 30, \mathrm{KW} / \mathrm{m}^{2}\right)$ depending on temperature $T_{2}$ of heated air $\left({ }^{\circ} \mathrm{C}\right)$, at ambient sea water temperature $T 1=$ $30^{\circ} \mathrm{C}$ and volumetric flow of circulating steam-air mixture of two liters per second, reduced to one $\mathrm{m}^{2}$ of insolation area. 


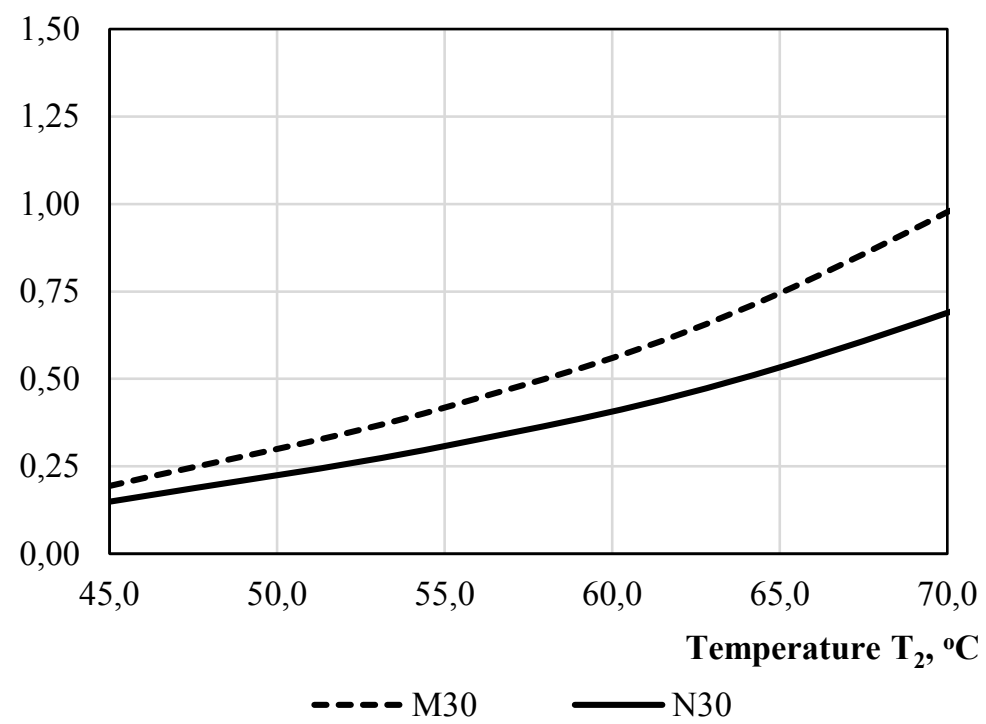

Fig. 3. Condensate mass flow rate (curve - M30, kg/hour) and power of required insolation (curve $\left.\mathrm{N} 30, \mathrm{KW} / \mathrm{m}^{2}\right)$ depending on the temperature of the heated air $\left({ }^{\circ} \mathrm{C}\right)$ inside the modular unit at ambient temperature of sea water of $30^{\circ} \mathrm{C}$ and volumetric flow of circulating steam-air mixture of 1.5 liters per second, reduced to one $\mathrm{m}^{2}$ of insolation area.

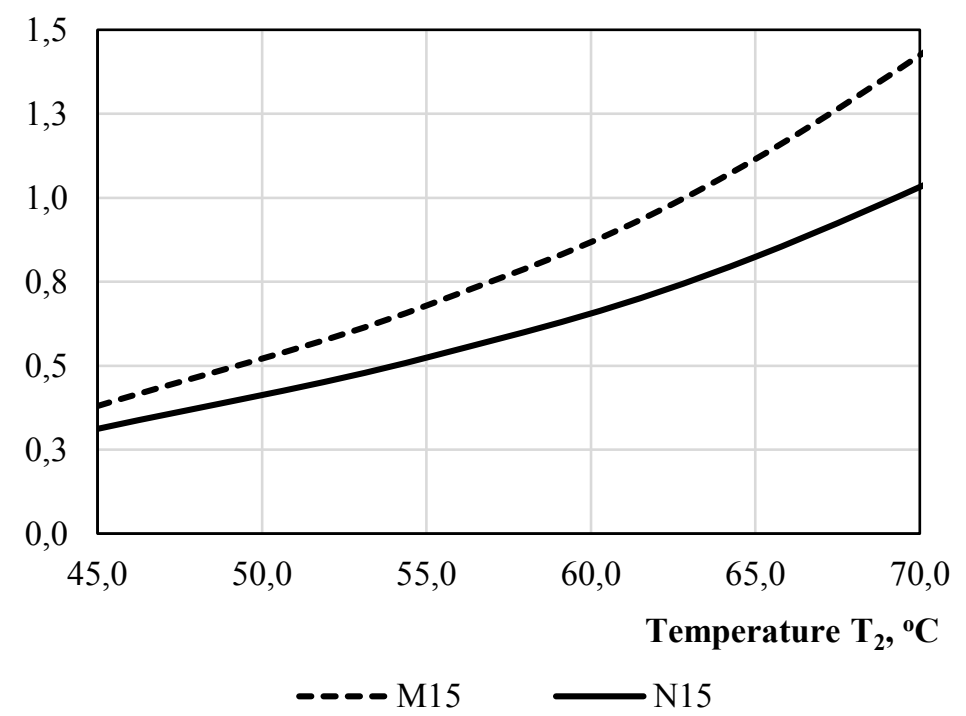

Fig. 4. Condensate mass flow rate (curve - M15, kg/hour) and power of required insolation (curve $\left.\mathrm{N} 15, \mathrm{KW} / \mathrm{m}^{2}\right)$ depending on the temperature of the heated air $\left({ }^{\circ} \mathrm{C}\right)$ inside the modular unit at ambient temperature of sea water of $15^{\circ} \mathrm{C}$ and volumetric flow of circulating steam-air mixture of two liters per second, reduced to one $\mathrm{m}^{2}$ of insolation area. 


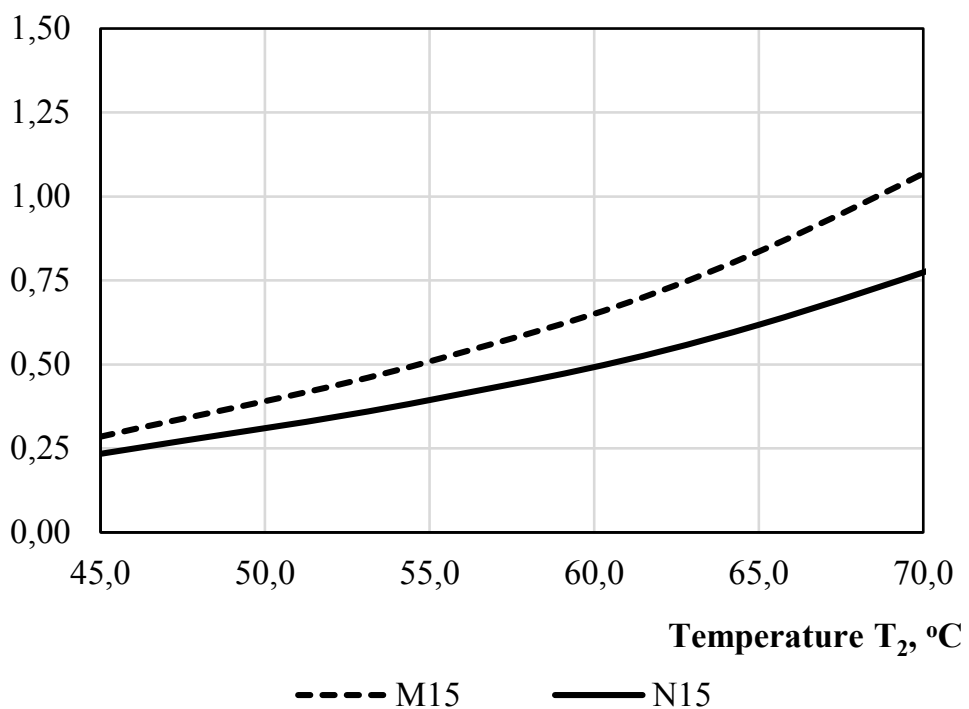

Fig. 5. Condensate mass flow rate (curve - M15, kg/hour) and power of required insolation (curve $\left.\mathrm{N} 15, \mathrm{KW} / \mathrm{m}^{2}\right)$ depending on the temperature of the heated air $\left({ }^{\circ} \mathrm{C}\right)$ inside the modular unit at ambient temperature of sea water of $15^{\circ} \mathrm{C}$ and volumetric flow of circulating steam-air mixture of 1.5 liters per second, reduced to one $\mathrm{m}^{2}$ of insolation area.

\section{Conclusions}

Closed thermodynamic air cycle allows the plant to operate without any preliminary cleaning of atmospheric air coming from the various impurities for heating and saturation. This circumstance constructively simplifies and reduces the price of a modular plant for obtaining water from the air.

From the equations of thermal energy balance and known reference data of the maximum moisture content of atmospheric air at various temperatures, characteristic curve were traced for determining the amount of condensate produced per unit of time, depending on the insolation power, which depends on the weather conditions. At the same time, the temperature of the ambient seawater and the performance of the fan are taken into account. Depending on the weather conditions, modular plants can obtain at low insolation up to 0.5 liters per hour and on a bright sunny day up to 1.4 liters per hour of fresh water, from a unit of insolation area. The blowers of the steam-air mixture in modular plants are low powered and they use solar photovoltaic cells. Obtained curves allow to perform design calculations of modular plants for getting pure, fresh water from moisture forcibly saturated air by the condensation method using the renewable solar energy.

\section{References}

1. V.A. Gorbachev, Mirovoe i natsional'noe khozyaystvo 4, 9 (2016)

2. R. Bahar, M.N.A. Hawlader, ICMAAE 2013 1, 1-5 (2013)

3. B.B. Tanganov, Sovremennye naukoemkie teknologii 7, 90-92 (2010)

4. V.V. Biryuk, Uspekhi sovremennoi nauki 12, 188-193 (2016)

5. M.K. Wittholz, B.K. O'Neill, C.B. Colby, D. Lewis, Desalination 229, 10-20 (2008) 
6. A. Magrini, M. Cattani, M. Cartesegna, L. Magnani, Energy Procedia 78, 1153-1158 (2015)

7. T. Strekalova, Behavioural Brain Research 277, 237-244 (2015)

8. K. Rajasekar, 2017 IOP Conf. Ser.: Mater. Sci. Eng. 183, 012032 (2017)

9. M.M. Shah, ASHRAE Transactions 120, 3-17 (2014)

10. Russian Federation Standard GOST R 12.3.047-98

11. L.D. Berman, Evaporative Cooling of Circulating Water (Pergamon Press, Oxford, 1961)

12. V.N. Yurenev, P.D. Lebedev, Thermotechnical Manual (Energiya, Moscow, 1976)

13. H. Hillier, Proc. of the I Mech E, Part B: J. of Eng. Man. 1, 295-322 (1953) 